Uludag Univ. J. Fac. Vet. Med.

33 (2014), 1,2: 83-86

\title{
Holstein-Friesian Irkı Bir Buzağıda Boynuz Köreltme Sonrası Beyin Hasarı
}

\author{
Volkan İPEK $^{1^{*}}$ Gülşah AKGÜL ${ }^{2} \quad$ Ahmet AKKOÇ $^{1} \quad$ M.Barış AKGÜL ${ }^{3}$
}

Geliş Tarihi: $13 \cdot 10.2014$

Kabul Tarihi: 30.10.2014

\begin{abstract}
Özet: Sinirsel bulgular gösteren 25 günlük bir buzağının ölüm sonrası nekropsisi yapıldı. Nekropside boynuz kaidelerinde deride yanıklar şekillenmiş olduğu gözlendi. Kafatası açıldığında sağ boynuz bölgesine denk gelen beyin dokusunda hemorajik ve nekrotik değişikliklerin şekillenmiş olduğu görüldü. Beyne atılan kesitlerde, kanama ve nekrozun beynin parenkiminde de bulunduğu dikkati çekti. Anamnezde sıcak dağlama ile boynuz köreltme işleminin yapıldığı öğrenildi. Alınan doku örneklerine mikroskobik inceleme için rutin takip prosedürleri uyguland. Mikroskobik incelemede beyinde yaygın nekroz ve kanama ile birlikte non-purulent meningitise rastlandı. Bazı parenkimal kan damarlarında fibrin trombüsleri dikkati çekti. Bu vakada beyin lezyonlarının koterizasyon kullanımı esnasında oluşan yüksek 1sı etkisinden kaynaklanabileceği düşünülmüştür.
\end{abstract}

Anahtar Kelimeler: Boynuz köreltme, buzağı, beyin hasarı.

\section{Brain Damage Following Dehorning in a Holstein-Friesian Calf}

\begin{abstract}
A calf was necropsied after showing clinical neurological signs and death. Skin burns were observed at the bases of horns. Necrotic and hemorrhagic changes were seen in brain tissue just beneath the right horn. Similar lesions were also noticed in the cut sections of brain parenchyma. In the anamnesis, it was told the calf was operated for the dehorning by using electrocauterization. Tissue samples were collected and processed routinely for the microscopical evaluation. Necrotic and hemorrhagic lesions and non-purulent meningitis were diagnosed in the microscopical examination of brain. Fibrin thromboses were also observed in some parenchymal blood vessels. We considered the brain lesions in the case may originatedue to high temperature used during the cauterization process.
\end{abstract}

Key Words: Dehorning, calf, brain damage.

\section{Giriş}

Sı̆̆ırlarda boynuz köreltme işlemi, sınırlandırılmış hayvanların kendilerine, bakıcılara ve personellere zarar verme riskini azaltmak için yaygın olarak uygulanan bir işlemdir ${ }^{1}$. Boynuz gelişimini önlemek için koryum ve çevre dokusu 1sı koterizasyonu, kimyasal koterizasyon ve küreme gibi çeşitli yöntemler kullanılarak yok edilir². Isı ile koterizasyon yaygın olarak uygulanan güvenilir bir yöntemdir fakat bu işlemin deneyimsiz kişiler tarafından lokal olarak uzayan sürelerde yapılması kafatası ve beyinde hasara yol açılabilmektedir ${ }^{3,4}$. Buzağ1larda ve oğlaklarda boynuz köreltme sonrası şekillenen beyin hasariyla ilgili raporlar bulunmaktadir ${ }^{4-8}$. Uzayan sürelerde bu tipteki uygulamalar merkezi sinir sistemindeki kan damarlarinda trombozlara sebep olarak iskemik lezyonlara yol açabilmektedir ${ }^{4,11}$. Bu raporda 25 gün-

\footnotetext{
1 Uludağ Üniversitesi Veteriner Fakültesi Patoloji Anabilim Dalı volkanipek@uludag.edu.tr

2 U.Ü. Veteriner Fakültesi İç Hastalıkları Anabilim Dalı

3 U.Ü. Veteriner Fakültesi Cerrahi Anabilim Dalı
} 
lük, Holstein-friesian ırkı bir buzağıda boynuz köreltme sonrası şekillenen beyin lezyonlarının klinik, nekropsi ve histopatolojik bulgularının değerlendirilmesi amaçlanmıştır. Yazarların bilgisine göre, ülkemizde boynuz köreltme sonrası şekillenen böyle bir tablo klinik, nekropsi ve histopatolojik yönleri ile daha önce rapor edilmemiștir.

\section{Materyal ve Metot}

Çalışmanın materyalini sinirsel bulgular göstererek Uludağ Üniversitesi Hayvan Hastanesi'ne getirilen 25 günlük, dişi HolsteinFriesian bir buzağ sistemine ait organlarla birlikte, tüm iç organlardan alınan doku örnekleri \%10’luk formaldehit tespitini ve rutin takip işlemlerini takiben parafine gömülerek 5 mikrometre kalınlığında kesitler alındı. Alınan tüm kesitlere rutin olarak Hematoksilen-Eozin (H-E), seçilen bazı kesitlere ise Brown-Brenn ve Fosfotungustik asit hematoksilen (PTAH) boyamaları yapıldı.

\section{Bulgular}

Anamnezde uygulanan boynuz köreltme işlemini takiben 8 gün sonra buzağının aniden depresif, anoreksik ve yan yatar duruma geldiği bildirildi. Klinik incelemede baş bölgesinde yaygın şişlik bulunduğu, konvülzyonların varl1ğ1, vücut 1sisinın 32,5 dereceye düşmüş olduğu, kalp atım oranının dakikada 32 olduğu ve yüzeysel solunum gözlendi. Buzağının orta derecede dehidre olduğu, müköz membranlarının anemik ve kapillar dolum zamanının uzamış olduğu görüldü. Anamnez ve klinik incelemeler sonucunda bulguların arı sokması veya kafa travması ile uyumlu olduğu düşünüldü. Kafa travmasına bağlı olası beyin ödemine yönelik olarak intavenöz kortikosteroid, \%20'lik mannitol, soğuk kompres ve muhtemel alerjik reaksiyona yönelik olarak da antihistaminik uygulamas1 yapıldı, ancak hayvan tedaviye cevap veremeden kısa bir süre sonra öldü ve nekropsi için Patoloji Anabilim Dalı'na gönderildi.

Nekropside, vücut genelinde herhangi bir lezyon gözlenmezken sağ boynuz kaidesi derisinde halka şeklinde, kafatasına kadar inen derin yanıklar şekillenmiş olduğu dikkati çekti (Resim-1). Kafatası açıldığında sağ boynuz bölgesine denk gelen beyin hemisferinde kanamalı ve nekrotik görünüm dikkati çekti (Resim-2). Beyin dilimlendiğinde parenşimin derin kısımlarına inen kanama ve likefaksiyon nekroz sahaları görüldü (Resim-3). Beynin alt yüzünün de kan pıhtısı ile örtülmüş olduğu gözlendi. Boynuzun koterize edildiği bölgeye karşılık gelen frontal kemiğin iç yüzeyinde herhangi bir lezyon dikkati çekmedi. Diğer iç organlarda makroskobik olarak lezyona rastlanmadi. Mikroskobik incelemede H-E ile boyalı kesitlerde, beyin parankiminde yaygın likefaksiyon nekrozuna, kanama alanlarına ve yer yer trombotik damarlara rastlandı (Resim-4). Orta şiddette nonpurulent meningitis tablosu dikkati çekti (Resim-5). Birçok meningeal ve parenkimal damar içerisinde ve dokuda yaygın şekilde çomak şekilli bakteriler görüldü. Brown-Brenn boyalı preparatlar incelendiğinde, gözlenen bakterilerin Gram pozitif çomaklar olduğu saptandı (Resim-6). Trombotik damarlardaki fibrin varlığının gösterilmesi amaciyla PTAH boyaması yapılarak damar lümenlerinde șekillenen fibrin trombüsleri demonstre edildi (Resim-7).

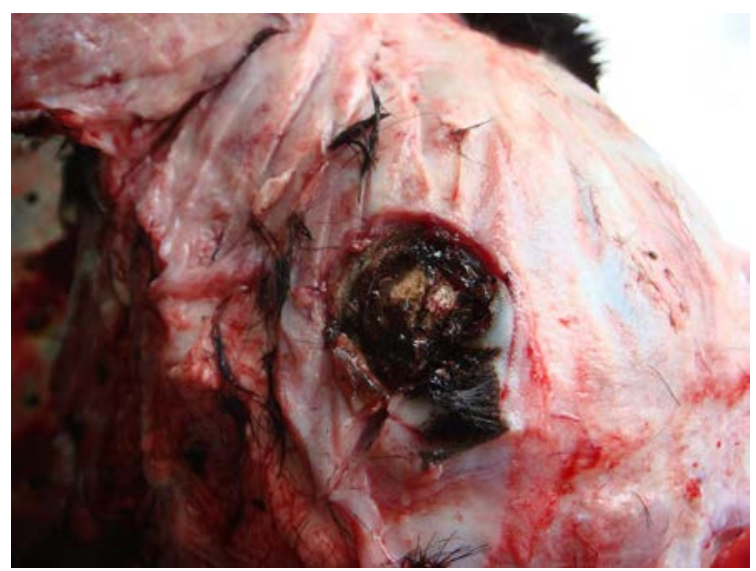

Resim-1. Boynuz bölgesi derisinde ve kemik dokuda yanık lezyonları.

Figure-1. Burn lesions in skin and bone at the horn region.

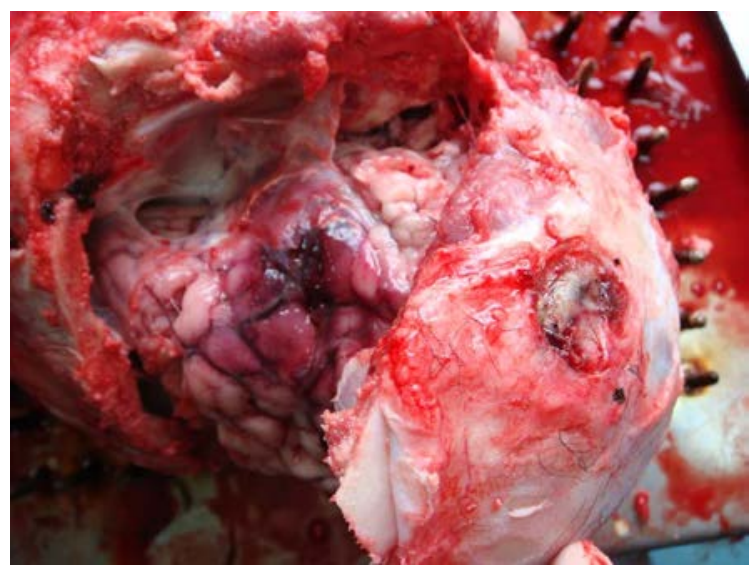

Resim-2. Să̆ boynuz bölgesinde yanık ve hemen altındaki beyin dokuda kanama ve nekroz.

Figure-2. Hemorrhagic and necrotic changes in brain just beneath the horn and necrosis in the base of right horn. 




Resim-3. Beynin sağ frontal lobunda ve kesit yüzünde kanama (oklar).

Figure-3. Hemorrhage in the right frontal lobe and its cut section of brain (arrows).

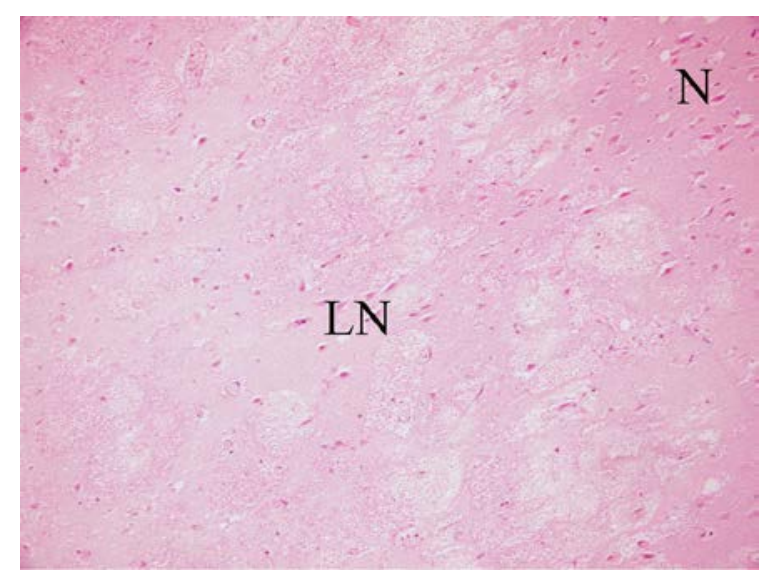

Resim-4. Beyinde normal (N) ve likefaksiyon nekrozuna (LN) uğramış alanlar, H-E, 100x.

Figure-4. Normal structure of brain $(N)$ and prominent liquefaction necrosis (LN), $H-E, x 100$.



Resim-5. Mononükleer lökosit infiltrasyonları ile meninkslerde kalınlaşma, H-E, 100x.

Figure-5. Thicknening of meninges with mononuclear leucocyte infiltrations, $H-E$, x100.



Resim-6. Meningeal damarlarda çok sayıda Gram pozitif çomak şekilli bakteriler, BrownBrenn, 400x.

Figure-6. Numerous Gram positive rod shape bacteria in meningeal vessel, Brown-Brenn, $x 400$.

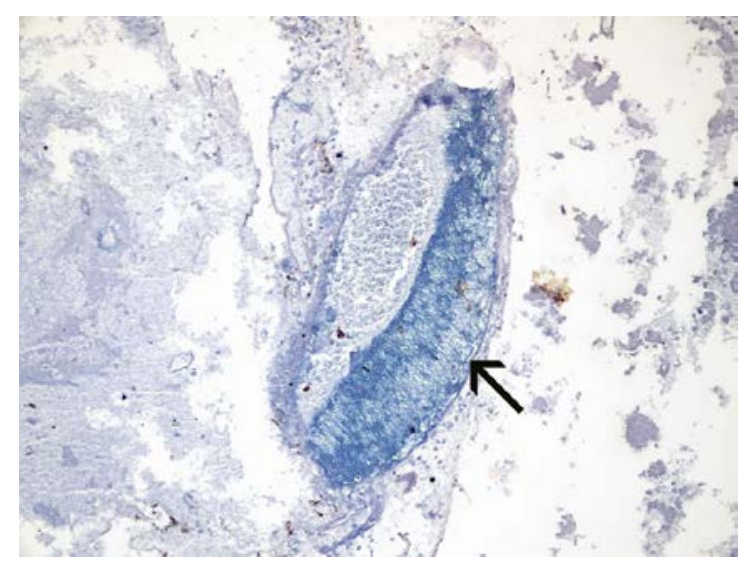

Resim-7. Beyin parenkiminde damar lümeninde fibrin trombozu (ok), PTAH, 100x.

Figure-7. Fibrin thrombosis in a parenchymal vessel in brain (arrow), PTAH, $x 100$.

\section{Tartışma ve Sonuç}

Buzağ 1 ve keçilerde boynuz köreltme sonrası çeşitli komplikasyonlar ile ilgili sınırlı sayıda rapor bulunmaktadır ${ }^{4-8}$. Bu komplikasyonlar arasında yaşlı ineklerde kanama ve frontal sinüzitis ile gençlerde yakıcı kimyasalların fazla uygulanması sonucu şekillenen deri yanıkları bulunmaktadır ${ }^{5}$. Is1 ile koterizasyon sonras1 meydana gelen beyin hasarında gözlenen bulgular içerisinde koterizasyon bölgesindeki kafatası segmentinde renk değişikliklerinin şekillendiği, beyin dokusunda ise hemoraji, nekroz, fibrin trombüsleri, inflamasyon ve suppuratif meningitis varlığ 1 rapor edilmiştir ${ }^{4,5}$. Bu vakada makroskobik olarak lezyonlu bölgenin hemen altındaki beyin dokusunda tek taraflı lokal kanama ve likefaksiyon nekrozunun şekillenmiş olduğu, mikroskobik incelemede ise bazı beyin damarla- 
r1 içerisinde fibrin trombüslerinin varlığı ve yaygın şekilde Gram pozitif çomakların varlığı gözlendi. Beyin parenkiminde yangısal hücre infiltrasyonlarına rastlanmad.

Merkezi sinir sisteminde ve diğer dokularda nispeten yüksek derecelerde $\left(55-60^{\circ} \mathrm{C}\right)$, 1sıya maruz kalma süresi kısa olsa dahi termal koagulasyon yoluyla hücre ölümü meydana gelebilmektedir ${ }^{9,10}$. Sabban ve Fahim, fareler üzerinde yaptıkları bir çalışmada lokal serebral hiperterminin damarlar üzerindeki etkilerini incelemiş ve beyin yüzeyindeki 1s1 43.1 dereceye ulaştı̆̆ında emboli ve arteriolar kontraksiyonları, birkaç dakika sonra da belirgin tromboz şekillendiğini gözlemlemişlerdir ${ }^{11}$. Hiperterminin aynı zamanda kan beyin bariyerinde de bozulmaya yol açtı̆̆ bölgesindeki yaralardan giriş yapan bakterilerin beyin dokusuna ulaşabileceğiyle ilgili de raporlar mevcuttur ${ }^{4,5}$. Bu vakada beyin lezyonlarının yüksek 1s1 etkisiyle meydana gelen damar trombozlarına bağlı olarak şekillendiği ve kan beyin bariyerindeki bozulma neticesinde, boynuz köreltme sirasında oluşan portantrelerden invaze olan ve beyin dokusuna ulaşan bakterilerin kendileri ve/veya toksinlerinin etkisiyle meningitis şekillenmiş olabileceği düşünülmüştür.

Ayırıcı tanıda, lezyonların tüm beyin dokusunda yaygın olarak şekillenmeyip, yalnızca koterize edilen boynuz altı bölgede bulunması bu lezyonun boynuz köreltme sonrası oluşmuş olabileceği şeklinde yorumlanmıştır. Sığırlarda klinik olarak sinirsel belirtiler ile seyreden tromboembolik meningoensefalitis (Histophilosis) hastalığından ayrımı konusunda; dokuda gözlenen bakterilerin Gram pozitif karakterde olması ve meninksler dıșında beyin parenkiminde yangısal hücre infiltrasyonlarının bulunmayışından faydalanılmıştır.

Dikkatsiz ve tecrübesiz kisiler tarafından yapılan koterizasyon işlemleri nedeniyle çok sayıda yaralanmalar ve bazen bu vakada gözlendiği şekilde 1sı etkisiyle beyin dokusuna varan lezyonlar şekillenebilmektedir. Klinikte sinirsel bulgularla seyreden olgularda ayırıcı tanıda koterizasyona bağlı beyin hasarı da düşünülmelidir. Hastadaki primer lezyonun beyindeki damar hasarı olduğu düşünüldüğünde, anamnezde koterizasyon bilgisinin edinilememesi, başka hastalıklara yönelme sonucu oluşan zaman kaybına ve damar permeabilitesini olumsuz etkileyebilecek ilaçların kullanılma riski açısından önem taşımaktadır. Bu nedenle bu tipteki olgularda anamnezin dikkatle alınması ve boynuz kaidelerinin muayenesi oldukça önemli görülmektedir.
Sonuç olarak sicak dağlama ile boynuz köreltme işlemleri sırasında hayvanlarda stres, deri yanıkları ve beyin hasarı gibi hayvan refahını olumsuz etkileyen sonuçlar meydana gelebilmektedir. Ülkemizde de önemli bir problem teşkil eden bu durumla ilgili uzman kişilerin görevlendirilmesi, gerekli takip ve kontrollerin yapılmas1, hayvan refahı ve ülke ekonomisi açısından önem taşımaktadır.

\section{Kaynaklar}

1. Graf B. and Senn M., 1999. Behavioural and physiological responses of calves to dehorning by heat cauterization with or without local anaesthesia. Applied Animal Behaviour Science, 62, 153171.

2. Vickers K.J., Niel L., Kiehlbauch L.M., Weary D.M., 2005. Calf response to caustic paste and hot-iron dehorning using sedation with and without local anesthetic. Journal of Dairy Science, 88, 1545-1459.

3. Kihurani D.O., Mbiuki S.M., Ngatia T.A., 1989. Healing of dehorning wounds. The British Veterinary Journal, 145, 580-585.

4. Thompson K.G., Bateman R.S., Morris P.J., 2005. Cerebral infarction and meningoencephalitis following hot-iron disbudding of goat kids. New Zealand Veterinary Journal, 53, 368-70.

5. Nation P.N. and Calder W.A., 1985. Necrosis of the brain in calves following dehorning. The Canadian Veterinary Journal, 26, 378-380.

6. Wright H.J., Adams D.S., Trigo F.J., 1983. Meningoencephalitis after hot-iron disbudding of goat kids. Veterinary Medicine/Small Animal Clinician, 78, 599-601.

7. Sanford S.E., 1989. Ontario. Meningoencephalitis caused by thermal disbudding in goat kids. The Canadian Veterinary Journal, 30, 832.

8. Dickson J., 1984. Brain damage in dehorned goat kids. The Veterinary Record, 114, 387.

9. McDannold N., Vykhodtseva N., Jolesz F.A., Hynynen K., 2004. MRI investigation of the threshold for thermally induced blood-brain barrier disruption and brain tissue damage in the rabbit brain. Magnetic Resonance in Medicine, 51, 913-23.

10. Barton J.K., Rollins A., Yazdanfar S., Pfefer T.J., Westphal V., Izatt J.A., 2001. Photothermal coagulation of blood vessels: a comparison of highspeed optical coherence tomography and numerical modelling. Physics in Medicine and Biology, 46, 1665-78.

11. El-Sabban F., Fahim M.A., 1995. Local cerebral hyperthermia induces spontaneous thrombosis and arteriolar constriction in the pia mater of the mouse. International Journal of Biometeorology, 38, 92-97. 